\title{
Renal Cell Carcinoma: Presentation and Management - A Single Centre Experience
}

\author{
Authors \\ Vaibhav Vikas ${ }^{1}$, Priyabrata Das ${ }^{2}$, Shanky Singh ${ }^{3}$, Jatin Soni ${ }^{4}$ \\ ${ }^{1,2,3,4}$ Department of Urology, Government Medical College, Thiruvananthapuram, Kerala, India \\ Corresponding Author \\ Priyabrata Das \\ C/O Baby Peter, Nirmal T.C. VI/2009, Medical College PO, Prasanth Nagar, \\ Thiruvananthapuram-695011, Kerala \\ Email id- priyabrat.das81@gmail.com, Phone- 9497345292
}

\begin{abstract}
Background: Renal cell carcinoma $(R C C)$ is the one of the most lethal urological carcinoma. It has a high incidence rate in western countries as compared to the Asian countries. There is paucity of literature about the incidence and types of RCC in Asian countries like India. The presentation of RCC has shifted from symptomatic towards incidental detection due to widespread availability of imaging techniques like ultrasonography. This study is a prospective observational study which aims at detecting the incidence and percentage of types of RCC in Southern India at a tertiary care health centre.

Material and Methods: All the patients of nephrectomy (over a period of one year) whose biopsy came out as renal cell carcinoma were included in the study. Data was analysed in terms of age at presentation, mode of presentation, stage at presentation, laterality and percentage of various types of histological types.

Results: Total 76 patients were enrolled in the study (57 males and 19 females) after excluding 11 patients who lost to follow up. $75 \%$ patients $(n=57)$ were males and $25 \%$ females $(n=19)$. Most common RCC was clear cell (76.31\%). Peak incidence was in 7th decade. Radical nephrectomy was done in 54 and partial nephrectomy in 22 patients.
\end{abstract}

Keywords: Renal cell carcinoma, incidental detection, paraneoplastic syndromes, radical nephrectomy, partial nephrectomy.

\section{Introduction}

Renal cell carcinoma (RCC) is the most common neoplasm of the genitourinary tract with incidence of $2-3 \%$ of all malignancy ${ }^{[1]}$. RCC is seen mainly in western world countries. It is less common in Asian countries, particularly in India. In recent years, the disease has been increasing at a very high rate and the incidence of the disease has seen reached peaks. Presentation of RCC has shifted more towards incidental detection due to developed imaging technologies like ultrasound and CT scan. There is paucity of data regarding RCC in India. The objective of this study was to assess the patients of RCC in respect to age distribution, sex distribution, mode of presentation, site of occurrence, risk factors, staging, treatment received and outcomes at a tertiary care centre in South India. This study will contribute to understanding the nature of kidney cancer in the sample population. It will be helpful in the formulation and planning of health care policies 
and strategies that improve RCC management and outcome in the future.

\section{Material and Methods}

Study Design: Prospective observational study.

Study Period: 1 year (July 2014 to June 2015).

Sample Size: Total 87 patients of malignant renal masses were enrolled in the study.

All the patients of renal tumor presenting to the OPD who underwent surgery were followed and their histopathology obtained. Patients whose pathology report turned out to be malignant renal masses were included in the study. Data were collected in terms of mode of presentation, age, sex, laterality, staging and type of surgery performed. Detail history regarding smoking, obesity, family history of renal tumors, hypertension, diabetes mellitus and chronic kidney disease were recorded. Total of 76 patients were registered in one year time after excluding 11 patients who lost to follow up. All the patients were followed for a period of two years. Locally advanced and metastatic RCC were referred to Department of Radiotherapy for adjuvant therapy.

\section{Inclusion Criteria}

1. All the patients of renal tumor presenting to urology OPD in one year time.

2. Patients of all age group were included.

3. Malignant renal tumors.

\section{Exclusion Criteria}

1. Patients who previously received treatment for renal tumors in the form of surgery, chemotherapy or radiotherapy somewhere else.

2. Benign renal masses.

\section{Results}

Total of 87 patients were diagnosed with malignant renal tumors over a period of 1 year (July 2014 to June 2015). 11 patients lost to follow up and hence were excluded from the study. Total patients included were 76 . Table 1 summarises the results of our study. Figure 1 shows the age distribution in our study. Out of 76 patients, 57 (75\%) were males and 19 (25\%) females (Male to female ratio 3:1). 55.26\% were right sided, $42.11 \%$ were left sided and $2.63 \%$
(2 patients) presented with bilateral renal tumors as a part of VHL syndrome. The rate of incidental detection in our study was $30.26 \%$ (It was higher because of widespread use of ultrasound for screening purposes). 27 patients (35.53\%) presented with hematuria as the initial complain. $43.42 \%$ were stage III, $28.95 \%$ stage II and $9.21 \%$ were stage IV at presentation. Most common histopathology in our study was Clear cell carcinoma in 58 patients (76.31\%) followed by Papillary carcinoma (10.53\%) and Chromophobe carcinoma (3.95\%). Renal Cell Sarcoma was found in 5 patients (6.59\%). Partial $(n=22)$ and radical $(n=54)$ nephrectomy were done for all the patients. 2 patients had infra hepatic vena cava tumor thrombosis which was removed by venacavotomy. All the patients were followed for 2 years. 12 patients died of which 8 were metastatic and 4 locally advanced disease.

\section{Table 1}

\begin{tabular}{|c|c|}
\hline \multicolumn{2}{|l|}{ Total Patients $(n)=87$} \\
\hline \multicolumn{2}{|l|}{ Lost to follow up $=11$} \\
\hline \multicolumn{2}{|l|}{ Death $=12$} \\
\hline \multicolumn{2}{|l|}{ Gender } \\
\hline Male & $57(75 \%)$ \\
\hline Female & $19(25 \%)$ \\
\hline \multicolumn{2}{|l|}{ Presentation } \\
\hline Hematuria & $27(35.53 \%)$ \\
\hline Incidental & $23(30.26 \%)$ \\
\hline Pain & $21(27.63 \%)$ \\
\hline Mass & $5(6.58 \%)$ \\
\hline \multicolumn{2}{|l|}{ Stage at Presentation } \\
\hline I & $14(18.42 \%)$ \\
\hline II & $22(28.95 \%)$ \\
\hline III & $33(43.42 \%)$ \\
\hline IV & $7(9.21 \%)$ \\
\hline \multicolumn{2}{|l|}{ Laterality } \\
\hline Right & $42(55.26 \%)$ \\
\hline Left & $32(42.11 \%)$ \\
\hline Bilteral & $2(2.63 \%)$ \\
\hline \multicolumn{2}{|l|}{ Histopathology } \\
\hline Clear Cell Carcinoma & $58(76.31 \%)$ \\
\hline Papillary & $08(10.53 \%)$ \\
\hline Chromophobe & $03(3.95 \%)$ \\
\hline Sarcoma & $05(6.59 \%)$ \\
\hline Poorly Differentiated & $02(2.62 \%)$ \\
\hline \multicolumn{2}{|l|}{ Type of Surgery } \\
\hline Radical Nephrectomy & $54(71.05 \%)$ \\
\hline Partial Nephrectomy & $22(28.95 \%)$ \\
\hline \multicolumn{2}{|l|}{ Approach of Surgery } \\
\hline Open & $46(60.53 \%)$ \\
\hline Transperitoneal Laparoscopic & $13(17.10 \%)$ \\
\hline Retroperitoneoscopic & $17(22.37 \%)$ \\
\hline
\end{tabular}


Figure 1.

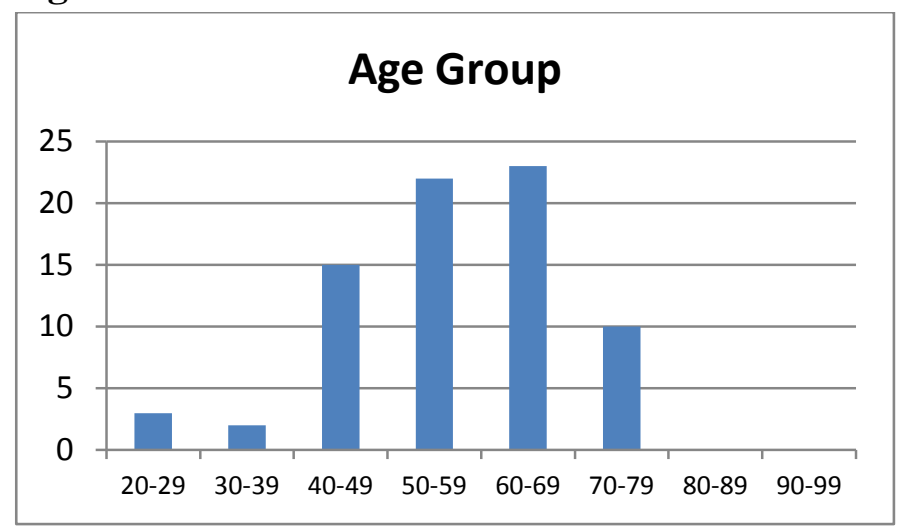

\section{Discussion}

RCC, which accounts for $2 \%$ to $3 \%$ of all adult malignant neoplasms, is the most lethal of the common urologic cancers $^{[2]}$. Approximately 65,000 new diagnoses of RCC are made each year in the United States, and 13,000 patients die of disease ${ }^{[2]}$. Overall, approximately 12 new cases are diagnosed per 100,000 population per year, with a male-tofemale predominance of $3: 2^{[2]}$. However, a higher male to female ratio was found in another study on Indian population ${ }^{[3]}$ may be because the males are greater exposed to the risk factors than female. This is primarily a disease of older adults, with typical presentation between 50 and 70 years of age ${ }^{[4],[5]}$. A large population-based cohort study in Japan ${ }^{[6]}$ revealed that risk factors for renal cell carcinoma (RCC) are male gender, old age, medical history of hypertension, high blood pressure level, diabetes mellitus, high body mass index (may be an increased exposure to the sex steroids estrogen and androgen), medical history of kidney disease, smoking, low physical activity, and westernized dietary habits ${ }^{[6]}$. Annual mortality-to-incidence ratio with RCC is significantly higher compared to other urological malignancies making it the most lethal urological malignancy ${ }^{[7]}$.

With the advent of widespread use of radiological imaging techniques, presentation of malignant renal tumors has shifted majorly towards incidental detection (more than $60 \%{ }^{[8]}$. Incidentally detected tumors are smaller in size and present at an earlier stage as compared to the symptomatic renal masses [9]. Incidental detection in India is still low as compared to western world. Symptomatic patients present with hematuria or flank pain or abdominal mass or combination of symptoms. Symptoms associated with RCC can be due to local tumor growth, hemorrhage, paraneoplastic syndromes, or metastatic disease. The classic triad of flank pain, gross hematuria, and palpable abdominal mass is now rarely found. This is fortunate because this constellation of findings almost always denotes advanced disease, and some refer to it as the "too late triad." Renal cell carcinoma may present with paraneoplastic syndromes like elevated erythrocyte sedimentation rate $(55.6 \%)$, hypertension $(37.5 \%)$, anemia $(36.3 \%)$, cachexia, weight loss $(34.5 \%)$, pyrexia $(17.2 \%)$, abnormal liver function $(14.4 \%)$, hypercalcemia $(4.9 \%)$, polycythemia $(3.5 \%)$, neuromyopathy $(3.2 \%)$ or amyloidosis $(2.0 \%)$ [10]. RCC arises from renal tubular epithelial cells. Clear cell carcinoma is most common variant and accounts for $70-80 \%{ }^{[11]}$. Primary renal sarcomas are rare tumors accounting for up to $3 \%$ of all renal malignancies ${ }^{[12]}$.

Treatment of RCC is nephrectomy (radical, partial or heminephrectomy). Post surgery the patients should be on strict follow up to detect recurrence as early as possible. Follow up protocol should be such that it should be compliant with the patient without financial burden. Follow up protocols are as mentioned in the tables 2 and 3 .

Table 2. Surveillance for Clinically Localized Renal Neoplasms: General Considerations ${ }^{[13]}$

\begin{tabular}{|c|c|}
\hline Follow up measure & Recommendation \\
\hline $\begin{array}{l}\text { Physical examination } \\
\text { and history }\end{array}$ & $\begin{array}{l}\text { - History and physical examination directed } \\
\text { at detecting signs and symptoms of } \\
\text { metastatic spread or local progression. }\end{array}$ \\
\hline Laboratory Testing & $\begin{array}{l}\text { - Basic laboratory testing, including BUN/ } \\
\text { creatinine, urinalysis, and eGFR, for all } \\
\text { patients. } \\
\text { Progressive renal insufficiency should } \\
\text { prompt nephrology referral. } \\
\text { CBC, LDH, LFTs, alkaline phosphatase, } \\
\text { and serum calcium per discretion of the } \\
\text { physician. }\end{array}$ \\
\hline $\begin{array}{l}\text { Central Nervous } \\
\text { System Imaging }\end{array}$ & $\begin{array}{l}\text { - Acute neurologic signs should lead to } \\
\text { prompt neurologic cross-sectional } \\
\text { imaging of the head or spine based on } \\
\text { localized symptoms. }\end{array}$ \\
\hline Bone Scan & $\begin{array}{l}\text { - Elevated alkaline phosphatase, clinical } \\
\text { symptoms such as bone pain, and/or } \\
\text { radiographic findings suggestive of a } \\
\text { bony neoplasm should prompt a bone } \\
\text { scan. } \\
\text { Bone scan should not be performed in the } \\
\text { absence of these signs and symptoms. }\end{array}$ \\
\hline
\end{tabular}


Table 3. Surveillance after Radical or Partial Nephrectomy ${ }^{[14]}$

\begin{tabular}{|c|c|}
\hline Follow up measure & Recommendation \\
\hline \multicolumn{2}{|c|}{ LOW-RISK PATIENTS (pT1N0MX) } \\
\hline Abdominal Imaging & $\begin{array}{l}\text { Partial Nephrectomy: } \\
\text { - } \text { Obtain a baseline abdominal scan (CT or } \\
\text { MRI within 3-12 months following } \\
\text { surgery. } \\
\text { - If the initial postoperative scan is } \\
\text { negative, abdominal imaging (US, CT, or } \\
\text { MRI) may be performed yearly for } 3 \\
\text { years based on individual risk factors. } \\
\text { Radical Nephrectomy: } \\
\text { - Patients should undergo abdominal } \\
\text { imaging (US, CT, or MRI) within 3-12 } \\
\text { months following surgery. } \\
\text { If the initial postoperative imaging is } \\
\text { negative, abdominal imaging beyond } 12 \\
\text { months may be performed at the } \\
\text { discretion of the clinician. }\end{array}$ \\
\hline Chest Imaging & $\begin{array}{l}\text { Partial and Radical Nephrectomy: Obtain a yearly } \\
\text { CXR for } 3 \text { years and only as clinically indicated } \\
\text { beyond that time period. }\end{array}$ \\
\hline \multicolumn{2}{|c|}{$\begin{array}{lcccc}\text { MODERATE- } & \text { TO } & \text { HIGH-RISK } & \text { PATIENTS } & \text { (pT2-4NOMX } \\
\text { pT[ANY]N1MX): PARTIAL OR RADICAL NEPHRECTOMY } & \\
\end{array}$} \\
\hline Abdominal Imaging & $\begin{array}{l}\text { - A baseline abdominal scan (CT or MRI) } \\
\text { within } 3-6 \text { months following surgery with } \\
\text { continued imaging (US, CT, or MRI) } \\
\text { every } 6 \text { months for at least } 3 \text { years and } \\
\text { annually thereafter to year } 5 \text {. } \\
\text { - Imaging beyond } 5 \text { years may be } \\
\text { performed at the discretion of the } \\
\text { clinician. } \\
\begin{array}{l}\text { Perform site-specific imaging as } \\
\text { symptoms warrant. }\end{array}\end{array}$ \\
\hline Chest Imaging & $\begin{array}{l}\text { - Obtain a baseline chest scan (CT) within } \\
3-6 \text { months following surgery with } \\
\text { continued imaging (CXR or CT) every } 6 \\
\text { months for at least } 3 \text { years and annually } \\
\text { thereafter to year } 5 \text {. } \\
\text { Imaging beyond } 5 \text { years is optional and } \\
\text { should be based on individual patient } \\
\text { characteristics and tumor risk factors. }\end{array}$ \\
\hline
\end{tabular}

Sivaramakrishna et al. mentioned in their study on 343 patients in north India that a third of the patients presented with stage III, although majority of the patients presented with stage ${ }^{[15]}$. The percentage of patients presenting with metastatic disease in India is higher than western countries because of heterogeneity of health facilities.

Pathological stage is the best predictor for RCC ${ }^{[16,17]}$. Prognostic indicators include nuclear grading, histological subtype ${ }^{[18]}$, functional status and molecular markers (Ki67, silver staining nucleolar organizing regions, proliferating cell nuclear antigens, and carbonic anhydrase expression) ${ }^{[19-21]}$. RCC can metastasize to unusual sites like lung, bone, liver, abdomen, and the retroperitoneum (decreasing order of frequency) ${ }^{[17,22]}$. Parienty et al. reported that $82 \%$ of patients with local recurrences were symptomatic ${ }^{[23]}$. Sandock et al found in their study that $73 \%$ of their patients with pulmonary metastases and $92 \%$ of abdominal metastases were symptomatic at presentation and suggested a protocol that relied on the detection of metastases based on symptoms ${ }^{[24]}$. An X-ray of the chest along with clinical evaluation detects pulmonary metastases in $100 \%$ of patients ${ }^{[25]}$.

5 year survival for stage I ranges from 80 to $100 \%$ ${ }^{[3,11]}$. Lymph node metastases is a poor prognostic sign and negatively affects survival (30\% survival rate) ${ }^{[26,27]}$. Survival rate in patients with systemic metastases is $<10 \% .{ }^{[11,28]}$. As there are several other prognostic factors have been described and heterogeneity in different literature, it is not possible to predict out come by only stage.

\section{Conclusion}

The detection of renal tumors has shifted towards younger age group and from symptomatic towards asymptomatic side. This shift is mainly due to widespread availability and use of ultrasonography for screening purposes. The most common RCC all over the world is clear cell carcinoma. Survival of RCC patients ranges from $90-100 \%$ in stage I to $<10 \%$ in stage IV. The results of our study are in concurrence with the literature in terms of types of RCC, mode of presentation, stage at presentation and outcome after surgery.

\section{References}

1. Jemal A, Siegel R, Xu J, Ward E. Cancer statistics, 2010. CA Cancer J Clin. 2010;60(5):277-300.

2. Siegel R, Naishadham D, Jemal A. Cancer statistics, 2013. CA Cancer J Clin 2013;63:11-30.

3. Lindblad P. Epidemiology of renal cell carcinoma. Scand J Surg 2004;93:88-96.

4. Pantuck AJ, Zisman A, Belldegrun AS. The changing natural history of renal cell carcinoma. J Urol 2001b;166:1611-23.

5. Wallen EM, Pruthi RS, Joyce GF, Urologic Diseases in America Project, et al. Kidney cancer. J Urol 2007;177:2006-19. 
6. Washio M, Mori M, Mikami K, Miki T, Watanabe Y, Nakao M, et al. Risk factors for renal cell carcinoma in a Japanese population. Asian Pac J Cancer Prev 2014; 15: 9065-9070.

7. Greenlee RT, Murray T, Bolden S, Wingo PA. Cancer statistics 2000. CA Cancer J Clin. 2000;50:57.

8. Silverman SG, Israel GM, Herts BR, et al. Management of the incidental renal mass. Radiology 2008;249:16-31.

9. Pantuck AJ, Zisman A, Rauch MK, Belldegrun A. Incidental renal tumors. Urology 2000;56:190-6.

10. Modified from Gold PJ, Fefer A, Thompson JA. Paraneoplastic manifestations of renal cell carcinoma. Semin Urol Oncol 1996;14:216-22.

11. Campbell SC, Lane BR. Malignant renal tumors. In: Wein AJ, Kavoussi LR, Novick AC, Partin AW, Peters CA, editors. Campbell-Walsh Urology. 10th ed. Philadelphia: Saunders Elsevier; 2012. p. 1413-74.

12. Pantuck AJ, Zisman A, Belldegrun AS. The changing natural history of renal cell carcinoma. J Urol 2001;166:1611-23.

13. Modified from Donat SM, Diaz M, Bishoff JT, et al. Follow-up for clinically localized renal neoplasms: AUA guideline. J Urol 2013;190:407-16.

14. Modified from Donat SM, Diaz M, Bishoff JT, et al. Follow-up for clinically localized renal neoplasms: AUA guideline. J Urol 2013;190:407-16.

15. Sivaramakrishna B, Gupta NP, Wadhwa P, Hemal AK, Dogra PN, Seth A, et al. Pattern of metastases in renal cell carcinoma: A single institution study. Indian $\mathbf{J}$ Cancer 2005;42:173-7.

16. Stephenson AJ, Chetner MP, Rourke K, Gleave ME, Signaevsky M, Palmer B, et al. Guidelines for the surveillance of localized renal cell carcinoma based on the patterns of relapse after nephrectomy. J Urol 2004;172:58-62.

17. Hafez KS, Novick AC, Campbell SC. Patterns of tumor recurrence and guidelines for follow up after nephron sparing surgery for sporadic renal cell carcinoma. J Urol 1997;157:2067-70.

18. Amin MB, Amin MB, Tamboli P, Javidan J, Stricker $\mathrm{H}$, de-Peralta Venturina $\mathrm{M}$, et al. Prognostic impact of histologic subtyping of adult renal epithelial neoplasms: an experience of 405 cases. Am J Surg Pathol. 2002;26:281-91.

19. Yasunaga Y, Shin M, Miki T, Okuyama A, Aozasa K. Prognostic factors of renal cell carcinoma: a multivariate analysis. J Surg Oncol 1998;68:11-5.

20. Aaltomaa S, Lipponen P, Ala-Opas M, Eskelinen M, Syrjanen K. Prognostic value of Ki-67 expression in renal cell carcinomas. Eur Urol 1997;31:350-3.

21. Morell-Quadreny L, Clar-Blanch F, Fenolossa-Enterna B, Perez-Bacete M, Martinez-Lorente A, Llombard-Bosch A. Proliferating cell nuclear antigen (PCNA) as a prognostic factor in renal cell carcinomas. Anticancer Res 1998;18:677-80.

22. Ljungberg B, Alamdari FI, Rasmuson T, Roos G. Follow-up guidelines for nonmetastatic renal cell carcinoma based on the occurrence of metastases after radical nephrectomy. BJU Int 1999;84:405-11.

23. Parienty RA, Richard F, Pradel J, Vallancien G. Local recurrence after nephrectomy for primary renal cancer: computerized tomography recognition. J Urol 1984;132:246-9.

24. Sandock DS, Seftel AD, Resnick MI. A new protocol for the followup of renal cell carcinoma based on pathological stage. J Urol 1995;154:28-31.

25. Montie JE. Follow-up after partial or total nephrectomy for renal cell carcinoma. Urol Clin North Am 1994;21:589-92.

26. Bassil B, Dosoretz DE, Prout GR Jr. Validation of the tumor, nodes and 
metastasis classification of renal cell carcinoma. J Urol 1985;134:450-4.

27. Phillips CK, Taneja SS. The role of lymphadenectomy in the surgical management of renal cell carcinoma. Urol Oncol 2004;22:214-23.

28. Chow WH, Devesa SS, Warren JL, Fraumeni JF Jr. Rising incidence of renal cell cancer in the United States. JAMA 1999;281:1628-31. 